\title{
Pengaplikasian Mosaik pada Produk Rumah Tangga Sebagai Peluang Usaha Baru Bagi Masyarakat Terdampak Pandemi Covid-19
}

\author{
Ariani*, Awang Eka Novia Rizali, Susy Irma Adisurya \\ Fakultas Seni Rupa dan Desain, Universitas Trisakti \\ *Email: arianirachman@trisakti.ac.id
}

Received: 09 Juny 2021; Revised: 26 July 2021; Accepted: 28 August 2021

DOI: http://dx.doi.org/10.37905/aksara.7.3. 1097-1106.2021

\begin{abstract}
Abstrak
Terpuruknya kondisi ekonomi di Indonesia akibat pandemi covid-19 telah berdampak pada semua lapisan masyarakat. Berbagai upaya dilakukan untuk memberdayakan masyarakat, salah satunya melalui kegiatan Pengabdian kepada Masyarakat (PkM). Tema yang diangkat dalam kegiatan kali ini adalah pengaplikasian desain mosaik pada produk rumah tangga sebagai peluang usaha baru bagi masyarakat terdampak pandemi Covid-19, dengan sasaran masyarakat yang bekerja sebagai pengemudi ojek, tukang las, dan pekerja bangunan. Kegiatan ini bertujuan memberikan pengetahuan dan keterampilan tentang pengaplikasian mosaik dari pecahan kaca dan keramik yang dikombinasikan dengan kayu bekas peti kemas menjadi produk nampan. Metode eksperimen dilakukan pada tahap persiapan, dilanjutkan dengan metode participatory action research dan pendampingan pada pelaksanaan pelatihan. Melalui pelatihan ini, para peserta menguasai keterampilan dalam membuat nampan kayu dan memiliki pemahaman estetika dalam menyusun pecahan kaca dan keramik menjadi mosaik. Hasil PkM berupa produk nampan yang fungsional dan bernilai estetis diharapkan dapat membuka peluang usaha baru bagi para peserta.
\end{abstract}

Kata kunci: mosaik, produk rumah tangga, peluang usaha baru, masyarakat terdampak pandemi Covid-19

\begin{abstract}
The deteriorating economic condition in Indonesia due to the COVID-19 pandemic has affected all levels of society. Various efforts have been made to empower the community, one of the efforts is through Community Service (PkM) activities. The theme raised in this activity is the application of mosaic designs in household products as a new business opportunity for people affected by the Covid-19 pandemic, targeting people who work as motorcycle taxi drivers, welders, and construction workers. This activity aims to provide knowledge and skills about the application of mosaics from broken glass and ceramics combined with wood waste from production into tray products. The experimental method is carried out at the preparation stage, followed by a participatory action approach and assistance in the implementation of the training. Through this training, the participants mastered the skills of making wooden trays and had an aesthetic understanding of composing broken glass and ceramics into mosaics. The results of PkM in the form of functional and aesthetically valuable tray products are expected to open new business opportunities for the participants.
\end{abstract}

Keywords: mosaics, household products, new business opportunities, people affected by the Covid-19 pandemic 


\section{PENDAHULUAN}

Pandemi covid-19 telah membawa dampak pada hampir semua aspek. Salah satunya adalah semakin terpuruknya kondisi perekonomian, tidak hanya di Indonesia, namun telah meluas ke seluruh dunia. Berbagai upaya telah dilakukan oleh pemerintah dan pihak-pihak berwenang untuk tetap menjaga kestabilan ekonomi agar tidak semakin memburuk. Namun hal tersebut bukan sesuatu yang mudah mengingat semakin dibatasinya semua akses untuk beraktivitas termasuk kegiatan untuk mencari nafkah. Satu demi satu perusahaan-perusahaan mulai mengurangi karyawannya bahkan perusahaan-perusahaan besar tidak sanggup lagi beroperasi dan mengumumkan kepailitannya. Masyarakat dari tingkat ekonomi rendah yang bekerja pada sektor informal adalah pihak yang paling merasakan dampak dari kondisi sulit ini. Jumlah pekerja informal diprediksi melonjak seiring terpuruknya usaha sektor formal akibat pandemi Covid-19 sehingga persaingan pun menjadi meningkat. Menghadapi kondisi ini, berbagai program pemberdayaan masyarakat dengan tujuan penguatan ekonomi masyarakat terus diupayakan. Salah satu upaya yang dapat dilakukan adalah dengan mengadakan pelatihan peningkatan keterampilan.

Fakultas Seni Rupa dan Desain Universitas Trisakti sebagai salah satu institusi pendidikan, memiliki kewajiban untuk membagikan ilmu seni rupa dan desain bagi masyarakat luas. Hal tersebut merupakan implementasi dari salah satu dharma Perguruan Tinggi yaitu Pengabdian kepada Masyarakat (PkM). Target kegiatan PkM ini adalah masyarakat di wilayah Asem Baris gang V, RT 05, RW 05. Sebelum pandemi, mereka bekerja di sektor informal yaitu sebagai pengemudi ojek, tukang las, dan pekerja bangunan, namun kemudian harus kehilangan pekerjaannya akibat wabah covid-19. Pelatihan ini merupakan kegiatan yang ke-2 setelah sebelumnya tim PkM FSRD memberikan pelatihan mengolah kayu bekas kemasan menjadi bangku. Dengan bekal pengetahuan ini mereka telah memiliki dasar-dasar keterampilan mengolah kayu sehingga akan memudahkan pada praktik berikutnya.

Pada kegiatan PkM kali ini, tim dosen lintas program studi beserta mahasiswa dan alumni mengadakan pelatihan mengolah pecahan kaca dan keramik menjadi elemen estetis pada produk rumah tangga berupa nampan. Pecahan kaca dan keramik yang disusun sedemikian rupa dengan komposisi yang mengikuti kaidah ilmu seni rupa dan desain tersebut kemudian diaplikasikan di atas nampan kayu yang telah dibuat sebelumnya. Pelatihan dilaksanakan sebanyak dua kali dengan materi yang berbeda, yaitu pelatihan mengolah kayu bekas peti kemas menjadi nampan dilanjutkan dengan pelatihan mengaplikasikan mosaik di atas nampan tersebut.

\section{METODE}

Sebelum pelaksanaan pelatihan, metode eksperimen dilakukan sebagai upaya menemukan pendekatan dalam memecahkan masalah berkaitan dengan pengolahan kayu bekas peti kemas dan keramik menjadi produk fungsional. Melalui metode ini, koordinator PkM dan tim pelaksana (anggota) terlebih dahulu melakukan diskusi dan uji coba untuk mendapatkan desain nampan yang sederhana dan komposisi mosaik yang mudah untuk diterapkan. Beberapa aspek desain seperti: bentuk, ukuran, fungsi, warna, finishing, dan sebagainya menjadi faktor yang harus diperhatikan untuk mendapatkan hasil berupa produk yang bernilai jual. Setelah mendapatkan materi yang sesuai, koordinator PkM kemudian melakukan sosialisasi mengenai rencana pelatihan tersebut 
kepada para peserta. Kegiatan ini dilaksanakan dengan menggunakan metode participatory action research, yaitu suatu metode pendekatan dalam proses pemberdayaan dan peningkatan partisipasi masyarakat, yang penekanannya pada keterlibatan masyarakat dalam keseluruhan kegiatan. Pendekatan ini dilaksanakan dengan proses yang bertujuan untuk memberikan pembelajaran dalam mengatasi masalah dan pemenuhan kebutuhan praktis masyarakat, serta produksi ilmu pengetahuan (Denzin dan Lincoln, 2009).

Metode pendampingan juga diberikan selama berjalannya kegiatan Pengabdian kepada Masyarakat ini. Kegiatan yang pada awalnya dijadwalkan dalam proposal akan dilaksanakan selama 1 hari, ternyata tidak dapat dilaksanakan secepat itu karena proses pembuatan produk memerlukan tahapan kerja yang harus dilalui. Para instruktur secara bergantian melakukan pendampingan selama proses pengerjaan produk dengan menerapkan standard protokol pencegahan penularan Covid-19. Peserta pelatihan adalah pria berusia antara 35-50 tahun, bekerja di sektor informal sebagai pengemudi ojek, pekerja bangunan, dan tukang las, dan merupakan kepala keluarga yang memiliki tanggung jawab dalam memberikan nafkah bagi keluarganya. Latar belakang pendidikan mereka adalah SMP (sebanyak 3 orang) dan SMA (sebanyak 3 orang). Peserta dibatasi sebanyak 6 orang mengingat ketentuan pemerintah selama pandemi, yaitu untuk membatasi berkumpulnya massa dalam suatu kegiatan.

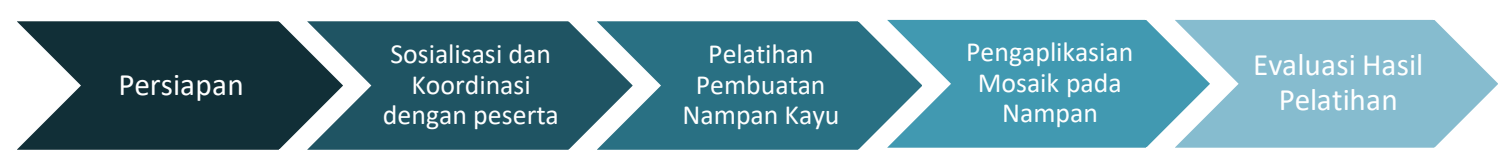

Gambar 1. Tahapan kegiatan PkM

\section{HASIL DAN PEMBAHASAN}

\section{Persiapan Pelatihan dan Sosialisasi}

Sebelum melaksanakan kegiatan Pengabdian kepada Masyarakat, koordinator acara terlebih dahulu melakukan diskusi berkaitan dengan pelatihan yang tepat untuk diberikan kepada masyarakat sasaran. Beberapa pertimbangan yang harus dipikirkan adalah:

1. Kegiatan yang diberikan harus dapat diikuti dan diimplementasikan oleh peserta yang rata-rata memiliki latar belakang pendidikan SMP dan SMA.

2. Keterampilan mengolah kayu sudah diperoleh pada pelatihan sebelumnya, sehingga kegiatan menitikberatkan pada peningkatan keterampilan dan pemahaman estetika peserta dalam mengolah pecahan kaca dan keramik.

3. Bahan-bahan dan peralatan yang digunakan mudah diperoleh dan harganya terjangkau.

4. Produk yang dibuat adalah produk sederhana namun bernilai jual.

Berdasarkan hasil diskusi dan pertimbangan-pertimbangan tersebut, maka tim PkM mencoba mempersiapkan sebuah produk sederhana berupa nampan (tray) yang menggunakan bahan kayu, dan mosaik sebagai elemen estetis. Nampan kayu dibuat dari kayu bekas peti kemas jenis kayu pinus atau jati belanda. Kayu jati belanda atau atau dalam Bahasa Jawa disebut dengan jati londo sebenarnya merupakan kayu pinus atau 
pinewood yang berasal dari pohon pinus (Pinus merkusii) dan banyak digunakan di berbagai belahan dunia karena memiliki serat atau corak tekstur kayu yang bagus dan memiliki permukaan serat yang halus. Di Indonesia sendiri kayu ini dikenal dengan nama kayu jati belanda atau kayu jati londo atau kayu pallet bekas peti kemas (Sutanto, 2017). Pemilihan produk nampan adalah dengan pertimbangan kemudahan dalam proses pembuatan.

Definisi mosaik menurut Kamus Besar Bahasa Indonesia (KBBI) V adalah seni dekorasi bidang dengan kepingan bahan keras berwarna yang disusun dan ditempelkan dengan perekat. Mosaik adalah seni hias kuno yang telah dimulai dari hampir 4000 tahun yang oleh orang-orang Mesopotamia dan Yunani. Tidak hanya bahan yang bervariasi dari satu peradaban, tetapi juga gambar yang dibentuk. Secara terminologi, mosaik berasal dari kata mouseieos (Yunani), berarti kepunyaan para muse atau sekelompok dewi yang melambangka seni (Muharrar, 2013).

Persiapan dilakukan dengan eksperimen membuat nampan kayu yang ditutup mosaik pada permukaannya. Eksperimen dilakukan dengan merujuk pada bentuk dan ukuran nampan yang sudah ada di pasar. Berdasarkan referensi tersebut, diperoleh ukuran nampan yang akan dibuat yaitu $20 \times 30 \mathrm{~cm}, 25 \times 30 \mathrm{~cm}$, dan $30 \times 40 \mathrm{~cm}$. Selanjutnya, eksperimen dilakukan dengan mencoba memotong pecahan-pecahan kaca dan keramik untuk disusun menjadi mosaik. Mengingat latar belakang peserta yang belum pernah mendapatkan pengetahuan tentang desain, maka pola yang akan dibuat pada mosaik adalah bentuk yang sederhana namun dengan beberapa pertimbangan estetika. Tahap selanjutnya adalah menyosialisasikan rencana kegiatan kepada masyarakat sasaran. Tujuannya adalah untuk mendapatkan kepastian waktu dan lokasi pelaksanaan.

\section{Pelaksanaan Pelatihan}

Mengingat terbatasnya waktu dalam 1 hari untuk melaksanakan 2 proses pengerjaan produk, maka pelaksanaan pelatihan dilaksanakan dalam 2 kali pertemuan. Pertemuan pertama untuk pembuatan nampan sedangkan pertemuan kedua diisi dengan pelatihan pengaplikasian mosaik pada nampan. Berikut adalah penjelasan pelaksanaan ke-2 tahapan kerja tersebut:

\section{Pelatihan Pembuatan Nampan Kayu}

Kegiatan ini dilaksanakan pada hari Sabtu, tanggal 26 Juni 2021, bertempat di halaman samping Balai Rakyat Tebet Timur, Jakarta Selatan. Dipilihnya lokasi ini karena berdekatan dengan domisili para peserta pelatihan yaitu daerah Asem Baris. Kegiatan diawali dengan sambutan dan perkenalan oleh koordinator PkM, dilanjutkan dengan penyampaian materi pengantar. Dalam kesempatan tersebut, koordinator memberikan penjelasan singkat tentang elemen desain serta prinsip dasar desain dan penerapannya dalam mosaik. Di samping itu perlu juga dijelaskan pentingnya hasil yang berkualitas yang tentunya berkaitan erat dengan penerapan aspek desain. Pentingnya pemahaman dan pengetahuan tentang desain menjadi salah satu faktor penting yang harus diberikan kepada para peserta pelatihan sebelum desain tersebut diwujudkan (Ariani, 2018). Bahan-bahan dan peralatan yang digunakan dalam pembuatan nampan kayu juga disampaikan pada kesempatan ini. 
Pelatihan dimulai dengan proses memotong kayu sesuai pola yang telah dipersiapkan pada saat tim PkM melakukan eksperimen. Hal tersebut dimaksudkan untuk memudahkan proses perakitan tiap bagian nampan yang membutuhkan ukuran yang presisi. Kayu yang telah dipotong selanjutnya dihaluskan dengan menggunakan mesin gerinda dan amplas, untuk kemudian dihubungkan antar bagian. Mesin gerinda berfungsi untuk menghasilkan finishing permukaan yang rata dan halus dengan cara mengikis permukaan kayu. Agar lebih halus, permukaan kayu kemudian dihaluskan kembali dengan amplas kayu. Secara fisik karakter kayu jati Belanda atau pinus lebih empuk dan berwarna cerah, tidak begitu keras sehingga relatif mudah diolah.
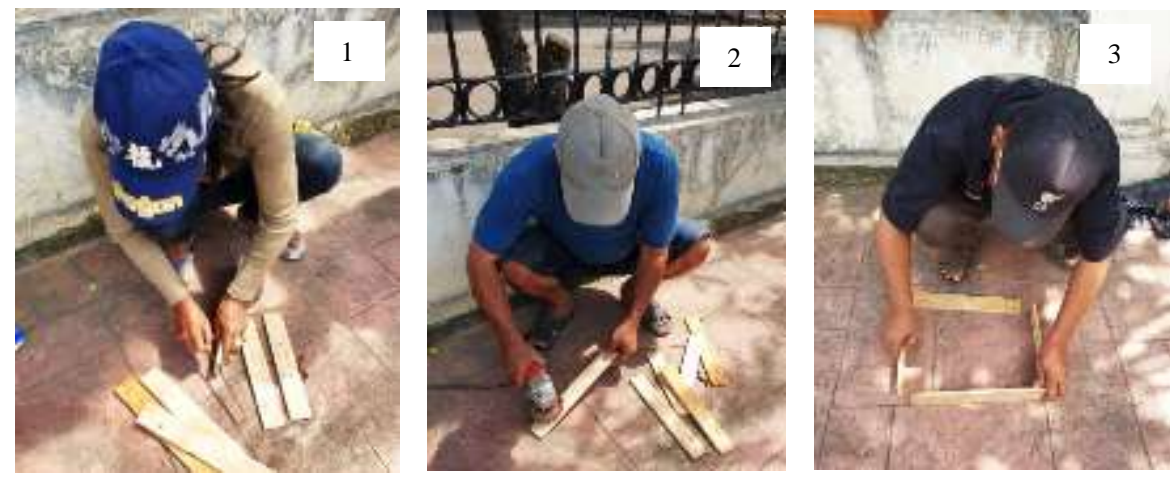

Gambar 2. Proses pemotongan kayu sesuai pola (1), penghalusan permukaan kayu dengan gerinda (2), proses perakitan untuk melihat tingkat presisi kayu (3).

Tahap berikutnya adalah meyambung antar bagian dengan menggunakan lem kayu yang diperkuat dengan paku. Proses ini membutuhkan ketelitian karena akan mempengaruhi hasil akhir bentuk nampan. Pada nampan ini, kayu disambung dalam bentuk siku dengan ujung kayu dipotong membentuk sudut $45^{\circ}$ (teknik adu manis). Dengan teknik ini, sambungan terlihat rapi, namun dibutuhkan tingkat presisi yang tinggi. Bagian tepi nampan dirakit terlebih dahulu hingga menyerupai frame, dilanjutkan dengan memasang bagian bawah nampan menggunakan multipleks. Tahap akhir pembuatan nampan adalah finishing dengan memberi lapisan vernish pada permukaan kayu.
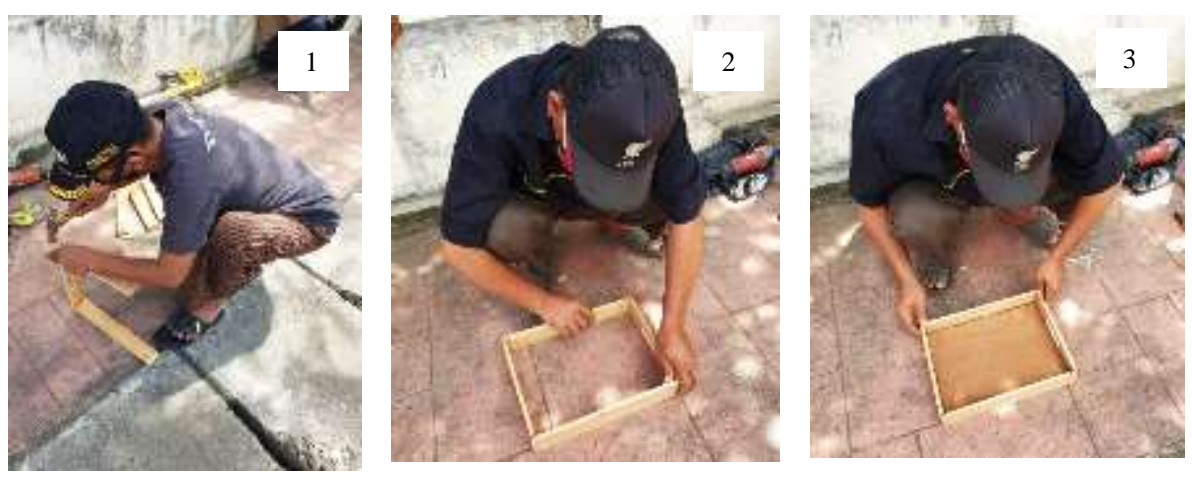

Gambar 3. Proses menggabungkan tiap bagian dengan lem dan paku (1), proses perakitan bagian tepi nampan (2), proses pemasangan bagian alas (3). 


\section{Pelatihan Pengaplikasian Mosaik Pada Nampan}

Pelatihan pengaplikasin mosaik pada nampan dilaksanakan pada hari Kamis, 22 Juli 2021, di lokasi yang sama dengan pelaksanaan pelatihan pembuatan nampan. Dalam pembuatan mosaik, pecahan kaca dan keramik yang telah dipotong dalam bentuk-bentuk tertentu kemudian disusun sedemikian rupa sehingga menghasilkan komposisi yang menarik. Pemilihan warna dan komposisi bentuk memegang peran penting untuk menghasilkan karya mosaik yang indah. Melalui pelatihan singkat ini, tim PkM mencoba memberikan wawasan tentang desain dan kepekaan dalam mengolah rasa sehingga para peserta dapat memunculkan satu karya seni yang memiliki nilai keindahan atau estetika (Adisurya dkk, 2021). Pada tahap ini, para peserta yang sebelumnya belum pernah mendapatkan pengetahuan tentang komposisi bentuk dan warna berusaha menerapkan materi yang telah disampaikan dengan didampingi oleh instruktur PkM.
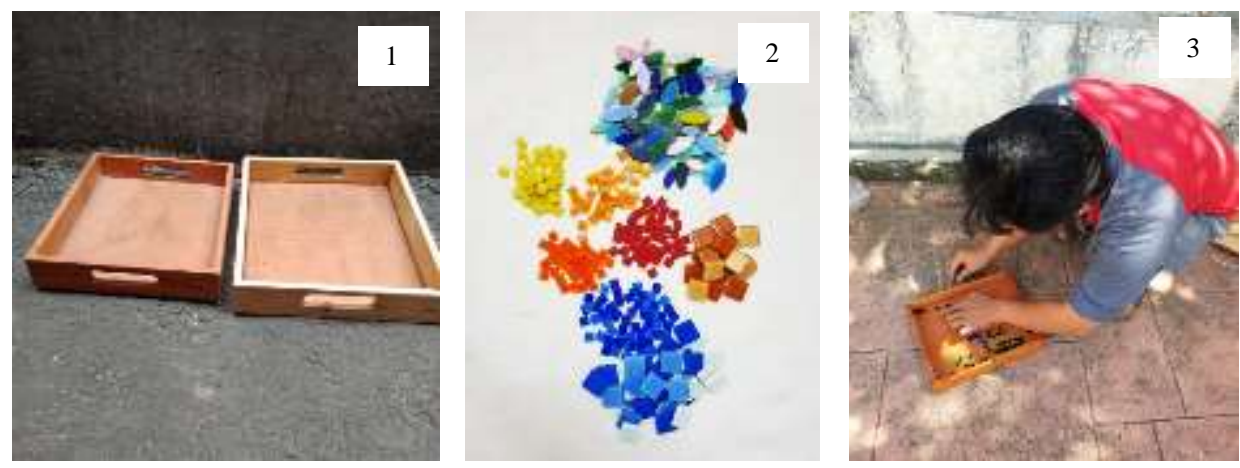

Gambar 4. Nampan kayu yang telah dibuat peserta (1), pecahan kaca dan keramik yang akan diaplikasikan menjadi mosaik (2), peserta pelatihan mencoba menyusun pecahan kaca menjadi komposisi bentuk tertentu (3)
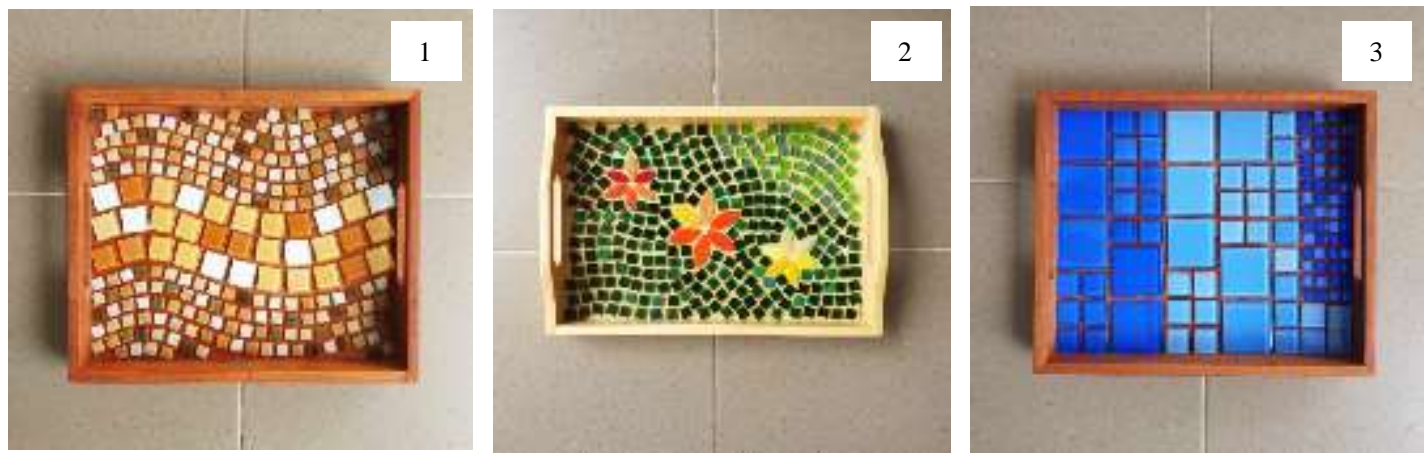

Gambar 5. Hasil penyusunan pecahan kaca dan keramik yang disusun sedemikian rupa mengikuti kaidah desain, sehingga menjadi komposisi yang menarik

Pada tahap selanjutnya, pecahan kaca dan keramik yang telah ditempel dengan lem kayu di atas nampan kemudian diberi semen putih pada celahnya. Tujuan pemberian semen ini adalah untuk menutup celah antar kaca atau keramik agar tidak ada kotoran yang masuk ke dalamnya. Tujuan yang lain adalah untuk menonjolkan bentuk dan warna mosaik. Seni mosaik dapat diterapkan ke setiap permukaan, dengan 
imajinasi dan bahan yang lengkap. Bahan yang digunakan dalam mosaik sangat beragam tergantung seniman yang membuatnya. Warna, tekstur, dan kepribadian sang seniman akan terlihat dari hasil karyanya tersebut (Locktov, 2005).
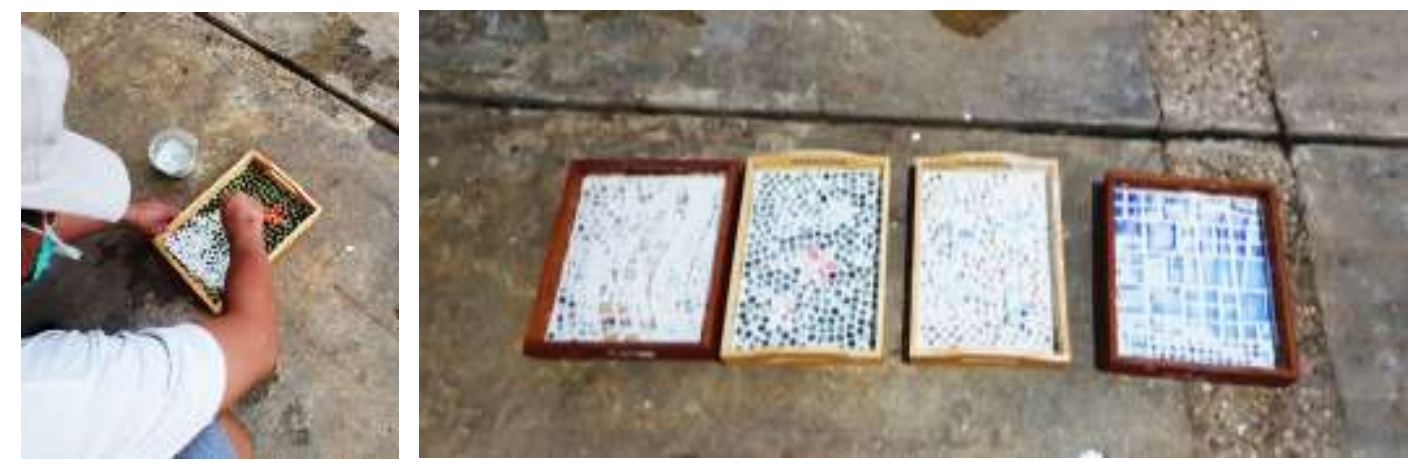

Gambar 6. Komposisi kaca dan keramik yang telah ditempel kemudian dilumuri dengan campuran semen putih dengan air

Hasil dari proses pengisian celah di antara pecahan kaca dan keramik dengan semen putih kemudian dirapikan dan dibersihkan permukaannya dengan lap atau spons basah. Proses ini bertujuan untuk menghilangkan bekas lumuran semen putih di atas permukaan kaca dan keramik, dan dilakukan pada saat semen putih masih lembab. Setelah dibiarkan beberapa saat hingga semen putih mengering, proses selanjutnya adalah finishing dengan membersihkan nampan dari percikan semen putih dan kotoran lainnya. Proses ini merupakan akhir dari pelatihan pengaplikasian mosaik di atas permukaan nampan.
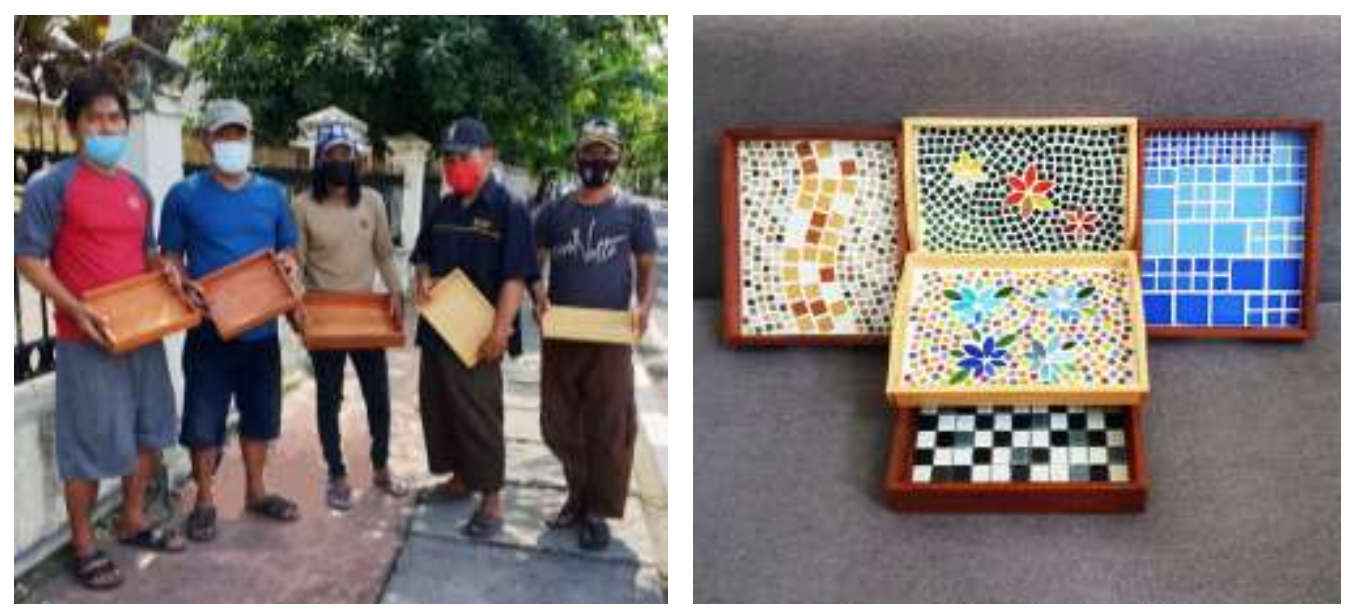

Gambar 7. Peserta dan nampan kayu yang telah mereka buat pada pelatihan pertama (gambar kiri), dan hasil akhir mosaik yang telah diaplikasikan di atas permukaan nampan (gambar kanan). 


\section{Evaluasi}

Hasil pengisian kuesioner oleh para peserta pada akhir kegiatan menjadi salah satu bahan evaluasi dari kegiatan Pengabdian kepada Masyarakat berjudul ini. Berdasarkan hasil pengisian kuesioner tersebut dapat disimpulkan bahwa:

1. Penjelasan materi pelatihan yang disampaikan oleh para instruktur sudah cukup jelas dan dapat diterima serta diimplementasikan dengan baik oleh para peserta pelatihan (P 1).

2. Proses pemotongan dapat dilakukan dengan baik, namun 1 peserta kurang presisi dalam memotong kayu (P 2).

3. Proses perakitan dapat dilaksanakan dengan baik, namun ada 1 peserta yang mengalami kesulitan karena pada saat memotong bagian ujung kayu, kemiringannya kurang presisi. Hal tersebut berakibat tidak bertemunya antar bagian siku sehingga harus dibuat ulang $(\mathrm{P}$ $3)$.

4. Proses finishing nampan dapat dikerjakan dengan baik, hal ini dapat dilihat dari pelaksanaan di lapangan dan hasil pengisian kuesioner 6 orang peserta yang menyatakan bahwa proses ini dapat dikerjakan dengan mudah (P 4).

5. Berdasarkan hasil pengisian kuesioner pada proses pengaplikasian mosaik, 3 peserta menyatakan bahwa mereka mengalami kesulitan dalam menyusun komposisi bentuk. Hal tersebut dapat dipahami mengingat mereka tidak memiliki latar belakang pendidikan seni atau pun wawasan tentang seni dan desain (P 5).

6. 3 peserta menyatakan belum memahami komposisi warna yang sesuai dengan kaidah seni rupa dan desain sehingga masih tergantung pada bimbingan instruktur (P 6).

7. Proses pengaplikasian semen putih dapat dilakukan dengan baik oleh seluruh peserta (P 7).

8. Proses finishing berupa membersihkan permukaan mosaik dapat dilakukan dengan baik oleh seluruh peserta (P 8).

Secara singkat, hasil pengisian kuesioner untuk melihat kemampuan peserta dalam memahami dan menerapkan materi pelatihan yang telah diberikan, dapat dilihat dari 8 pertanyaan dalam kuesioner yaitu sebagai berikut:

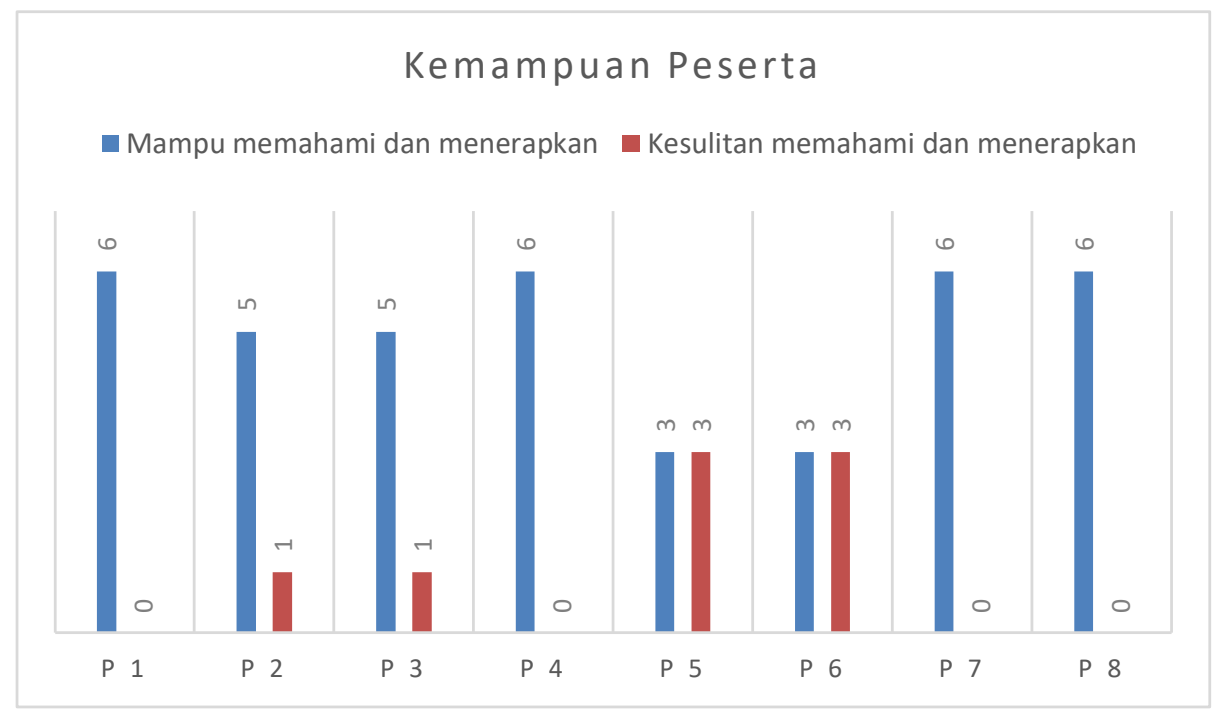

Gambar 8. Diagram yang menunjukkan kemampuan peserta dalam memahami dan menerapkan setiap proses dalam pelatihan. 


\section{HASIL KEGIATAN}

Pelatihan pembuatan nampan kayu dilaksanakan selama kurang lebih 5 jam, yaitu mulai pukul 09.00 hingga 14.00, dengan hasil berupa 6 buah nampan kayu yang cukup rapi. Para peserta telah memperoleh keterampilan dalam mengolah kayu pada pelatihan sebelumnya, sehingga mereka tidak mengalami kesulitan dalam pembuatan nampan ini. Sedangkan pada pelatihan pengaplikasian mosaik pada nampan, sebagian peserta mengalami kesulitan dalam memahami komposisi warna dan bentuk. Oleh karena itu, mereka harus didampingi oleh instruktur untuk mendapatkan hasil mosaik yang menarik. Setelah melihat hasil akhir dari mosaik yang dibuat, para peserta berharap pengetahuan tentang seni rupa dan desain seperti ini dapat mereka dalami lebih lanjut. Mereka memiliki keinginan untuk mengembangkan keterampilan ini dengan lebih serius hingga dapat menjadi peluang untuk mendapatkan tambahan income.

Luaran hasil pelaksanaan kegiatan Pengabdian kepada Masyarakat (PkM) ini adalah HKI (Hak Kekayaan Intelektual) berupa hak cipta poster kegiatan dan publikasi di jurnal nasional. Rencana selanjutnya, hasil kegiatan berupa nampan kayu dengan mosaik sebagai elemen estetis ini akan didaftarkan ke HKI Desain Industri. Materi yang disampaikan dalam pelatihan ini memiliki relevansi dengan mata kuliah Nirmana, Pengetahuan Bahan, Desain Interior, dan Desain Produk, sehingga dapat menambah referensi pada mata kuliah tersebut.
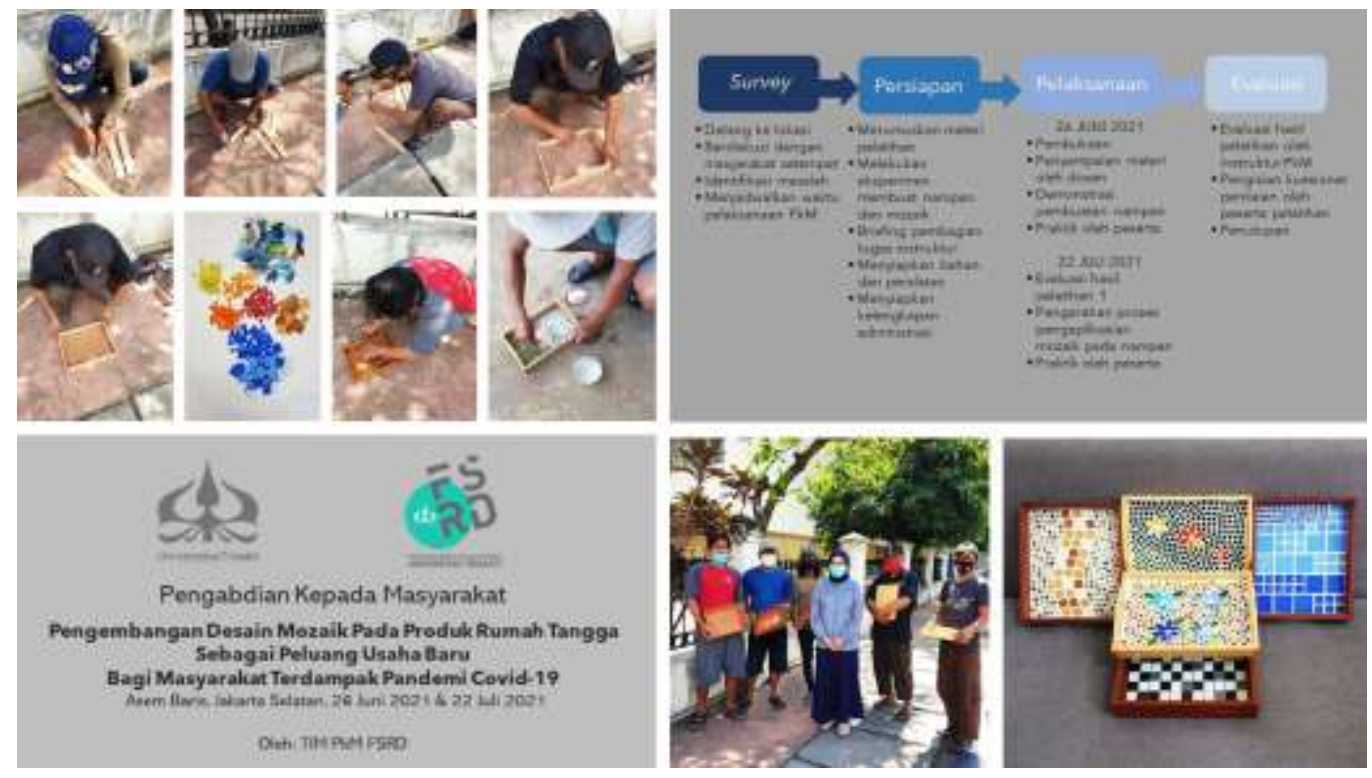

Gambar 9. Poster kegiatan yang telah didaftarkan ke DJKI pada HKI Hak Cipta

\section{KESIMPULAN}

Peserta pelatihan dapat mengikuti kedua pelatihan ini dengan baik. Kesulitan yang dialami peserta pada proses pemahaman desain beserta implementasinya dapat diatasi dengan rajin mencoba dan memberikan pelatihan serupa pada kesempatan yang berikutnya. Para peserta mengharapkan pelatihan ini dapat dilaksanakan secara berkelanjutan, sehingga hasil pelatihan berupa produk nampan dengan elemen estetis mosaik ini dapat menjadi peluang usaha baru untuk meningkatkan perekonomian mereka selama pandemi. 


\section{DAFTAR PUSTAKA}

Adisurya, S. I., Ariani, Wilastrina, A., Wiemar, R. (2021). Peningkatan Kreativitas Remaja Karang Taruna Dalam Membuat Hiasan Kepala dan Masker untuk Tari Betawi Kreasi. Jurnal Aksara, 07(02), 177-190. DOI: http://dx.doi.org/10.37905/aksara.7.2.177-190.2021.

Ariani. (2018). Pemanfaatan Botol Plastik Bekas Menjadi Media Tanam (Pot) Di Lahan Sempit. Abdimas Pedagogi, Jurnal Ilmiah Pengabdian kepada Masyarakat, 2(1), 1-7. DOI: http://dx.doi.org/10.17977/um050v2i1p1-7.

Denzin, N. K. dan Lincoln, Y. S. (2009). Handbook of Qualitative Research. Yogjakarta: Pustaka Pelajar.

Locktov, J. (2005). Mosaic Art and Style, Design for Living Environments. United Kingdom: Apple Press

Muharrar, S. (2013). Kreasi Kolase Montase, Mozaik Sederhana. Jakarta: Penerbit Erlangga.

Sutanto J, Gede P, C., Tedjokoesoemo, P. (2017). Upcycle Limbah Kayu Palet Jati Belanda Menjadi Wadah Modular Serbaguna untuk Anak-Anak (Studi Kasus: Kota Surabaya). Jurnal Intra, 5(2), 829-838. 